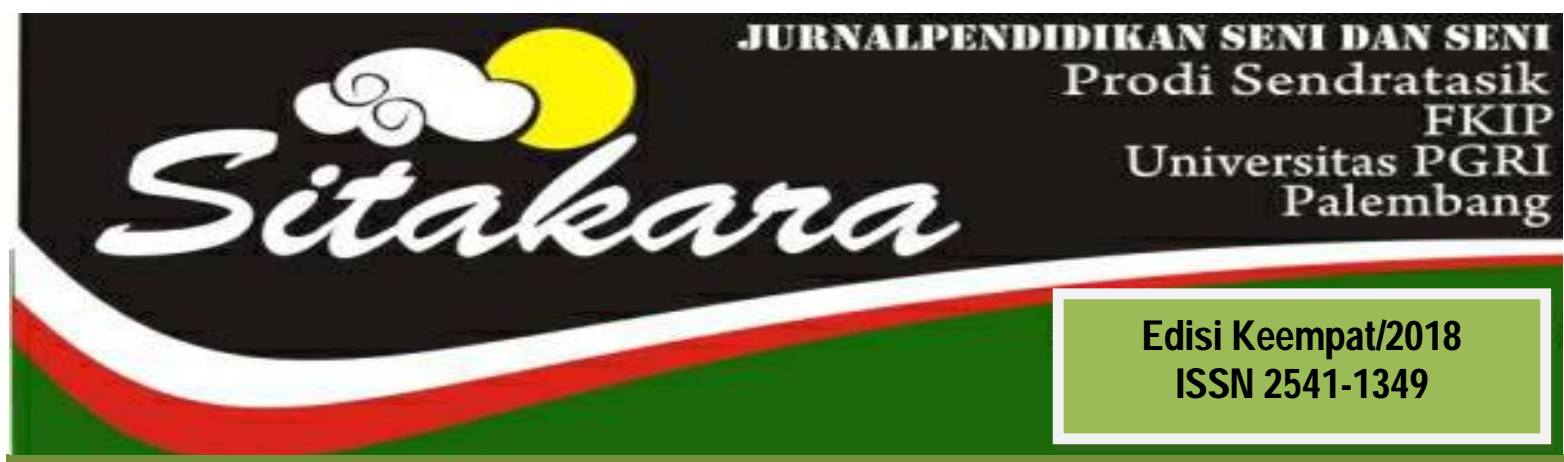

Objektifitas Imajinatif Dalam Pertunjukan Teater

Mohammad A rfani

Makna Estetis Dalam Simbol Tatto

Novdaly Fillamenta

Desain A tas (Air D esign) D alam Dimensi Estetik Pertunjukan Karya Tari

Efita Elvandari

Pengaruh M etode D emonstrasi D alam Pembelajaran Tari Burung Bermain

Pada Kegiatan Ekstrakurikuler D i SM P N egeri 36 Palembang

Ria Moulina A driamul

Gerak: Perjalanan D ari M otif Ke Komposisi Tari

Rully Rochayati

Sastra Lisan Dalam Kesenian Saluang D endang Sumatera Barat

Nofroza Yelli

Rangsang A udio Sebagai M otivasi Pada Penciptaan Karya

Tari Tunggu Tubang Dalam Pembelajaran Koreografi di Universitas

PG RI Palembang

Treny Hera

M otif Bungo Pacik Pada Tenunan Songket Palembang

Mainur

Konsep Kreatifitas Wallas D alam Proses Penciptaan Tari Tepak Keraton

Nurdin

A nalisis Bentuk Gerak Tari Turak Di Sanggar Studio Lingga

Kota Lubuklinggau

Sisca Fitriani

Bentuk Figur Tokoh Wayang Kulit Palembang

Robert Budi Laksana 


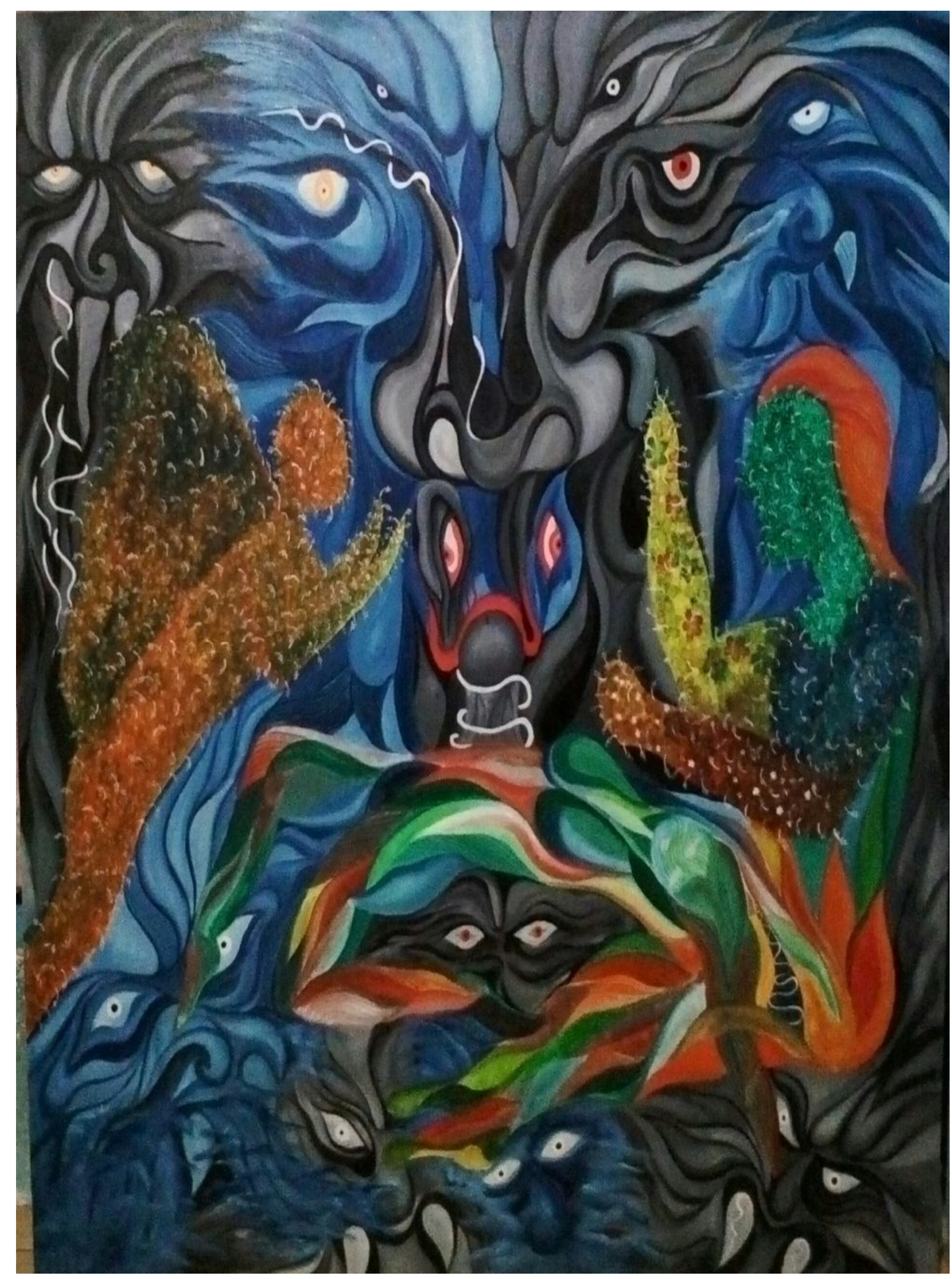




\section{SITAKARA}

\section{JURNAL PENDIDIKAN SENI DAN SENI BUDAYA}

Edisi 4, Februari 2018

\section{DEWAN REDAKSI}

1. PenanggungJawab

2. KetuaDewan Redaksi

3. WakilDewanRedaksi

4. Sekretaris

5. PenyuntingPelaksana

6. Penyunting Ahli

7. Setting
:

: Dra. Andinasari, M.M., M.Pd.

: RullyRochayati, M.Sn

: Nofroza Yelli, M.Sn

: Treny Hera, S.Pd., M.Sn

: 1. Efita Elvandari, M.Sn

2. Arfani, S.Pd., M.Sn

: 1. Prof. Dr. Triyono Bramantyo, P.Hd (ISI Yogyakarta)

2. Dr. DessyWardiah, M.Pd (UPGRI)

3. Dr. Slamet, M.Hum (ISI Surakarta)

4. Yayan Hariyansyah, M.Sn (UIGM)

: 1. Mainur, S.Pd.,M.Sn

2. I Komang Kerta Yana, S.Si

\section{AlamatRedaksi}

Program StudiPendidikanSendratasik JurusanPendidikanKesenian FKIP Universitas PGRI Palembang Jl. A. YaniLorongGotongRoyong 9/10 Ulu Palembang Telp. 0711-510043 Fax. 0711-514782 E-mail: jurnalsitakarasendratasik@yahoo.com 


\section{DAFTAR ISI}

Objektifitas Imajinatif D alam Pertunjukan Teater

M ohammad A rfani

Makna Estetis D alam Simbol Tatto

Novdaly Fillamenta

D esain A tas (Air D esign) D alam D imensi Estetik Pertunjukan Karya Tari

Efita Elvandari

Pengaruh M etode D emonstrasi D alam Pembelajaran Tari Burung Bermain 25 Pada Kegiatan Ekstrakurikuler Di SM P N egeri 36 Palembang

Ria M oulina Adriamul

G erak: Perjalanan D ari M otif Ke Komposisi Tari

Rully Rochayati

SastraL isanD al amK esenianSaluangD endang Sumatera Barat

N ofroza Yelli

Rangsang Audio Sebagai M otivasi Pada Penciptaan Karya

Tari Tunggu Tubang Dalam Pembelajaran Koreografi di Universitas

PG RI Palembang

Treny Hera

Motif Bungo Pacik Pada Tenunan Songket Palembang

Mainur

Konsep K reatifitas Wallas D alam Proses Penciptaan Tari Tepak Keraton N urdin

Analisis Bentuk G erak Tari Turak Di Sanggar Studio Lingga

Kota Lubuklinggau

Sisca Fitriani

BentukFigurT okohWayangKulit Palembang 


\title{
SASTRA LISAN DALAM KESENIAN \\ SALUANG DENDANG SUMATERA BARAT
}

\author{
Oleh: \\ Nofroza Yelli \\ (Program Studi Pendidikan Sendratasik FKIP Universitas PGRI Palembang)
}

\begin{abstract}
ABSTRAK
Tulisan ini merumuskan masalah tentang bagaimanabentuk sastra lisan dalam kesenian Saluang Dendang di Sumatera Barat, dengan tujuan untuk dapat mendeskripsikan bentuk sastra lisan yang menjadi ciri khas kesenian Saluang Dendang di Sumatera Barat.Kajian Pustaka menguraikan tentang definisi sastra lisan secara umum dan Saluang Dendang Minangkabau.Metode yang digunakan dalam penelitian ini adalah kualitatif yaitu mendeskripsikan hasil yang telah diperoleh melalui teknik pengumpulan data observasi, wawancara dan dokumentasi.Dari hasil data diperoleh bahwa sastra lisan yang dalam kesenian Saluang Dendang terdiri dari dua bentuk yakni berisikan tentang fenomena sosial masyarakat pada umumnya yang dituangkan dalam syair sedih dan gembira.Syair ini secara spontan diciptakan oleh para pendendang sesuai dengan konteks acara.
\end{abstract}

Kata Kunci: Sastra Lisan, Dendang.

\section{A. PENDAHULUAN}

\section{Latar Belakang}

Kesenian tradisi di Indonesia pada umumnya berisikan sastra lisan dalam menyampaikan isi dari cerita.Sastra ini disampaikan menggunakan irama tersendiri yang merupakan ciri khas dari kesenian itu sendiri.Diantaranya kesenian tradisi yang menggunakan sastra lisan yakni kesenian Saluang Dendang yang berkembang di Sumatera Barat.Kesenian Saluang Dendangmerupakan salah satu kesenian yang menggunakan alat musik Saluang sebagai alat musik pokok untuk mengiringi vokal (dendang).Masyarakat pendukung kesenian tersebut menyebutnya dengan acara bagurau(bersenda gurau).Hal tersebut dikarenakan adanya aktivitas senda gurau yang diungkapkan melalui pantun-pantun
Dendang yang bersifat sindiran yang ditujukan kepada penonton, sehingga tercipta suasana canda penuh tawa.

Berkaitan dengan pertunjukan Saluang Dendang di Minangkabau, Andar Indra Sastra menjelaskan dalam tulisannya "Bagurau dalam Basaluang: Cerminan Budaya Konflik", bahwa istilah bagurau lebih dipahami oleh masyarakat pendukungnya sebagai suatu kegiatan pertunjukan Saluang. Pada pertunjukan ini mencerminkan suasana senda gurau (Sastra, 1999:156). Dengan adanya pernyataan tersebut diketahui bahwa bagurau adalah suatu aktivitas sekelompok orang yang ingin bergembira yang diwujudkan dalam bentuk pertunjukan tradisional yaitu pertunjukan Saluang Dendang.

Pertunjukan Saluang Dendang selain dihadirkan sebagai media untuk bersenda 
gurau, juga dimanfaatkan sebagai pertunjukan yang bersifat komersil. Hal ini terlihat dari konteks acaranya yakni ditampilkan dalam berbagai acara perayaan, seperti acara sosial dan acara-acara adat, seperti: sunnah rasul, dan baralek kawin. Kesenian Saluang Dendang ini sangat menarik untuk diteliti karena terdapat seni sastra didalamnya yakni syair dalam bentuk pantun yang menjadi ciri khas kesenian Sumatera Barat.

\section{Rumusan Masalah}

Berdasarkan latar belakang di atas maka rumusan masalah yang akan diuraikan dalam penelitian ini yakni "Bagaimana bentuk sastra lisan dalam kesenian Saluang Dendangdi Sumatera Barat?"

\section{Tujuan penelitian}

Penelitian ini bertujuan untuk mendeskripsikan bentuk sastra lisan dalam kesenian Saluang Dendang di Sumatera Barat.

4. Tinjauan Pustaka

$$
\text { Mursal Esten (1978:9) menuliskan }
$$

bahwa sastra adalah pengungkapan dari fakta artistik dan imajinatif sebagai manifestasi kehidupan manusia. Melalui bahasa sebagai medium dan memiliki efek yang positif terhadap kehidupan manusia tersebut.

Sastra lisan adalah berbagai turunan verbal yang memiliki ciri-ciri sebagai karya sastra pada umumnya, yang meliputi puisi, prosa, nyanyian, dan drama lisan. Sastra lisan adalah bagian dari tradisi lisan berupa pesan- pesan, cerita-cerita yang diwariskan secara lisan kepada generasinya, (Vansina, 1985: 2728).

Tulisan yang menjelaskan tentang pertunjukan Saluang Dendang di Minangkabau adalah Andar Indra Sastra (1999:156).Tulisan tersebut membahas tentang pertunjukan Saluang Dendang. PertunjukanSaluang Dendang di sini merupakan ungkapan senda gurau yang disampaikan melalui pantun-pantun dendang yang berupa sindiran-sindiran terhadap penonton sehingga tercipta suatu keakraban dalam perkumpulan tersebut yang berpotensi mengundang suasana konflik, baik pada saat pertunjukan berlangsung maupun pertunjukan sebagai konflik.

\section{B. METODE PENELITIAN}

\section{Metode kualitatifakandigunakan} untukmengumpulkan data, baik itu data-data yang berupa observasi, wawancara dengan seniman atau masyarakat pendukung pertunjukan Saluang Dendang,bahkan dokumentasi terkait pertunjukan kesenian Saluang Dendang.Sebagaimana Conny (2010:18), mengatakan bahwa metode kualitatif bertujuan untuk memahami dan mengerti gejala, fakta, realita, dan peristiwa yang dialami oleh manusia.Terkait pernyataan ini, metode kualitatif sangat dibutuhkan untuk menguraikan bentuk sastra lisan yang terdapat dalam kesenian Saluang Dendang di Sumatera Barat pada umumnya.Teknik pengumpulan data 
dilakukan melalui; 1) Teknik observasi yakni mengamati secara langsung pertunjukan Saluang Dendangyang diadakan di beberapa daerah di Sumatera Barat, sehingga dapat melihat bagaimana interaksi sosial yang terjadi saat itu melalui media sastra lisan. 2) Teknik wawancara dilakukan dengan memberikan pertanyaan-pertanyaan kepada narasumber terkait kesenian Saluang Dendang. Beberapa narasumber diantaranya pemain Saluang, dan pendendang.3)Teknik dokumentasi yaitu mengumpulkan data-data berupa dokumen terkait kesenian Saluang Dendangdiantara data audio dan visual.

\section{PEMBAHASAN}

Kesenian Saluang Dendangmerupakan kesenian tradisi yang tumbuh dan berkembang di Sumatera Barat.Kesenian ini menggunakan alat musicSaluang sebagai pengiring dendang atau vocal.Saluang merupakan alat musik tiup yang terbuat dari bambu dan mempunyai empat lubang sebagai penghasil nada.

Kesenian Saluang Dendangbiasanya dipertunjukkan dalam acara hiburan masyarakat seperti pernikahan, acara adat, dan penggalangan dana.Pertunjukan ini bisa ditampilkan pada malam hari ataupun siang hari, sesuai dengan konteks kegiatan.

$$
\text { Pendukung pertunjukan Saluang }
$$

Dendang terdiri dari satu orang pemain Saluang (tukang Saluang), beberapa orang sebagai pendendang.Pada pertunjukan
Saluang Dendang, dendang merupakan salah satu bagian penting dalam struktur penyajiannya.Dendang (lagu) berisi pantun yang menceritakan tentang fenomena sosial masyarakat pada umumnya, baik mengisahkan tentang ratapan ataupun kegembiraan.

\section{Syair dendang yang berisi ratapan (Dendangratok)}

Dendangratok berawal dari ratapan kematian yang merupakan tangisan dengan kata-kata.Seiring dengan perkembangan zaman, hal ini dihadirkan dalam pertunjukan saluang dendang(Erizal dan Efrinon, 1987;25).Disebut Dendangratok oleh karena dendang yang dibawakan berirama sedih atau meratap.Ratapan ini dalam bahasa minang disebut ratok.Dengan demikian dendang ratok adalah lagu dendang yang berirama sedih atau meratap.Selain dapat dirasakan melalui irama dendang, kesedihan ini juga terlihat dalam beberapa lirik dendang yang dibawakan oleh pendendang tersebut.BeberapaDendangratok dalam kesenian Saluang Dendangdapat dilihat dari syair berikut.

1. Salailah lilin sibarantai Hari manjalang sanjo rayo Padam manjalang parak siang Sajak ketek badan marasai Nan lah gadang coiko pulo Antah pabilo mancubo sanang

Teriemahan: Nyalakanlah lilin sibarantai Hari menjelang senja Padam sebelum subuh Sejak kecil badan sengsara 
Hingga besarpun masih seperti ini

Entah kapan merasa senang

Makna:

Menceritakan tentang kehidupan

seseorang, dimana dalam

kehidupannya ia memiliki nasib yang

kurang beruntung atau sengsara.

Nasib ini dirasakan sejak ia kecil

hingga besar.

2. Jikok bajalan disanjo rayo

Singgah sabanta didakek simpang

Urang namokan kampuang teleang

Sajak ayah kini tiado

Kamalah badan ka manompang

Badan nan hanyo tungga babeleang

Terjemah:

Kalau berjalan dihari senja

Mampir sebentar didekat simpang

Orang namakan kampung teleng

Sejak ayah sekarang tiada

Kemana badan akan menumpang

Badan hanyalah anak tunggal

Makna:

Seorang anak tunggal yatim piatu, sekarang tidak ada keluarga semenjak orang tuanya meninggal.

3. Asa lai lapeh ka untuak makan Hujan paneh ka denai hadang

Siang malam denai tahankan

Coiko nasib si anak dagang

Terjemah:

Asalkan dapat untuk makan

Hujan dan panas akan dihadang

Siang malam akan ditahan

Seperti ini nasib anak dagang

Makna:

Nasib pedagang kecil bekerja keras mencari nafkah.
4. Jauah arah jauah tujuan

Badan nan kini di rantau urang

Asa dapek ka untuak makan

Hujan jo paneh denai hadang

Terjemah:

Jauh arah jauh tujuan

Badan sekarang dirantau orang

Asalkan dapat untuk makan

Hujan dan panas saya hadang

Makna:

Nasib anak rantau mencari nafkah dengan kerasnya rintangan.

5. Jauah jalan nan den tampuah

Hujan paneh nan dihadang

Pituah mandeh den turuikkan

Usah adiak bahati rusuah

Cinto ka adiak indak ka hilang

Walaupun jauah dari pandangan

Terjemah:

Jauh jalan yang saya tempuh

Hujan dan panas yang dihadang

Amanah ibu saya turuti

Jangan adek berhati sedih

Cinta untuk adek tidak akan hilang

Walaupun jauh dari pandangan

Makna:

Meninggalkan orang yang disayang demi sebuah pekerjaan di tempat yang jauh.

6. Jikok ditimbang alah batahun

Ayah bajalan ka nagari urang

Tiok malam denai tatagun

Ayah kanduang bilo kapulang

Terjemah:

Kalau ditimbang sudah bertahun

Ayah pergi ke negeri orang

Tiap malam saya termenung

Ayah sayang kapan pulang

Makna: 
Seorang anak yang merindukan kepulangan sang ayah yang sedang mencari nafkah di negeri orang.

\section{Syair dendang yang berisi kegembiraan}

\section{(Dendang Gembira)}

Disebut dengan Dendang gembira dikarenakan isi dari syair menceritakan tentang hal-hal yang bersifat kebahagiaan bahkan lelucon. Dalam hal ini pada umumnya syair dendang akan membuat suasana penuh tawa.

Beragam Dendang gembira yang dibawakan pada pertunjukan ini yaitu dendang yang berjudul Singgalang, Kincia Tuo, Larek Nagari dan sebagainya. Dalam menyajikan dendang gembira inilah para pendendang menyajikan pantun spontanitas untuk menciptakan suasana tawa dari penonton dengan sindiran yang diberikan kepada beberapa orang yang hadir pada pertunjukan berlangsung, sehinggamenggambarkan interaksi sangat akrab antara pendendang dengan penoton yang ada pada saat itu.Selain secara spontanitas dari pendendang, penonton juga diperbolehkan untuk menyampaikan permintaan kepada pendendang untuk membawakan syair yang ditentukan oleh penonton tersebut. Misalnya menyampaikan salam kepada seseorang yang disayangi, maka dalam hal ini pendendang akan menyampaikan salam tersebut langsung kepada orang yang dimaksud dengan irama dendang.

Berikut akan diuraikan beberapa syair yang berisi kegembiraan.
1. Nan kabalai ka Padang Magek Nan kapulang hari lah sanjo

Si Ujang basirawa pendek

Dari bawah angin mangguriaknyo

Terjemahan:

Pergi kepasar ke Padang Magek

Pulangnya di sore hari

Si Ujang bercelana pendek

Dari bawah angin masuknya

Makna:

Sebuah sindiran kepada seorang penonton yang saat itu memakai celana pendek.

2. Gandang ciek jo gandang duo Pacah pariuak parandangan Mati ndak makan lai ka dicubo Asa lai dapek bapandangan

Terjemah:

Gendang satu dan gendang dua

Pecah panci berderaian

Mati tak makan akandicoba

Asalkan duduk berpandangan

Makna:

Seseorang yang mengungkapkan begitu besar cinta yang dia punya kepada kekasih.

3. Daun salam daun sarai

Pambuek tumih sambalado

Minyak apo nan uda pakai

Sadang lalok takana juo

Terjemah:

Daun salam daun serei

Untuk tumis sambel cabe

Minyak apa yang uda pakai

Saat tidur teringat jua

Makna:

Seseorang yang sedang jatuh cinta.

4. Duduak basandiang pengantin baru Aleknyo rami tuo jo mudo 
Urang mananti babaju biru

Salamaik manampuah hiduik baru

Dulunyo surang kini baduo

Bahagia sampai ka anak cucu

Terjemah:

Duduk bersanding pengantin baru

Pestanya ramai tua dan muda

Orang menanti berbaju biru

Selamat menempuh hidup baru

Dulu sendiri sekarang berdua

Bahagia sampai ke anak cucu

Makna:

Ucapan selamat menempuh hidup baru kepada pengantin pada saat acara pesta pernikahan.

5. Pai manjalang sanjo hari

Singgah sabanta di Koto tuo

Baranti tantang pandakian

Talamak sanda minum kopi

Hari lah tambah laruik juo

Bini dirumah manantikan

Terjemah:

Pergi menjelang senja

Mampir sebentar di Koto Tuo

Berhenti di pendakian

Enaknya sender minum kopi

Haripun semakin larut
Istri dirumah menatikan

Makna:

Sindiran kepada salah satu penonton bahwa istri menyuruh pulang kerumah.

\section{SIMPULAN}

Saluang Dendangmerupakan salah satu kesenian tradisi Minangkabau yang yang terdapat sastra lisan di dalamnya sebagai media utntuk menyampaikan pesan kepada penonton. Kesenian ini diiringi oleh satu buah alat musik tradisi yakni Saluang Darek. Dalam pertunjukan Saluang Dendang terdiri dari satu orang pemain Saluang dan beberapa orang sebagai pendendang. Jenis syair yang terdapat pada pertunjukan ini yaitu syairyang berisi ratapan atau kesedihan seperti nasib buruk dan kematian,serta syair yang berisi ungkapan kegembiraan seperti sindiran lucu kepada penonton, kisah percintaan, hingga ucapan bahagia kepada pengantin baru.

\section{DAFTAR PUSTAKA}

Erizal dan Efrinon. 1987. Sekilas Dendang Minang. Padangpanjang: Akademi Seni Karawitan Indonesia.

Esten, Mursal. 1978. Kesusasteraan: Pengantar Teori dan Sejarah. Bandung: Angkasa.

Sastra, Andar Indra. 1999. "Bagurau dalam Basaluang: Cerminan Budaya Konflik", Tesis, Yogyakarta: Universitas Gadjah Mada.

Semiawan, Conny R. 2010. Metode Penelitian Kualitatif. Jakarta: Grasindo.

Vansina, Jan. 1985. Oral Tradition as History. Madison, Wisconsin: University of Wisconsin Press. 


\section{KETENTUAN PENULISAN ARTIKEL JURNAL SITAKARA}

1. Naskah berbahasa Indonesia bertemakan Seni Budaya yang meliputi hasil penelitian pengajaran seni budaya, cabang seni, dan kebudayaan.

2. Naskah harus asli dan belum pernah dimuat dalam media lain. Naskah dapat berupa hasil penelitian perorangan atau kelompok. Naskah ditulis dengan cara-cara yang sesuai dengan ketentuan penulisan artikel ilmiah menggunakan bahasa Indonesia yang baku, berupa ketikan, beserta soft line dalam CD-RW atau dengan mengirimkan email pada redaksi Jurnal Sitakara dengan alamat email: jurnalsitakarasendratasik@yahoo.com, spasi 1,5 jenis huruf Arrial Narrow ukuran 12, dengan panjang naskah antara 8-15 halaman pada kertas A4.

3. Artikel hasil penelitian memuat:

JUDUL

NAMA PENULIS

ABSTRAK

\section{A. PENDAHULUAN}

B. METODE PENELITIAN

C. HASIL DAN PEMBAHASAN

D. SIMPULAN

4. Artikel kajian konseptual memuat JUDUL

NAMA PENULIS

ABSTRAK

PENDAHULUAN

SUB JUDUL

SIMPULAN

DAFTAR PUSTAKA

\section{: XXX (HURUF KAPITAL)}

: (disertai jabatan dan institusi)

: (Bahasa Indonesia yang memuat 100- 150 kata diikuti kata kunci, dengan jenis huruf Arrial Narrow dan ukuran huruf 11 serta dicetak tebal).

: (Memuat latar belakang masalah, tinjauan pustaka Secara ringkas, masalah dan tujuan penelitian).

: (Berisi simpulan)

: XXX (HURUF KAPITAL)

: (disertai jabatan dan institusi)

: (Bahasa Indonesia yang memuat 100- 150 kata diikuti kata kunci, dengan jenis huruf Arrial Narrow dan ukuran huruf 11 serta dicetak miring)

: (Memuat latar belakang masalah, tinjauan pustaka secara ringkas, masalah penelitian dan tujuan penelitian)

: Sesuai dengan kebutuhan (tanpa numbering)

: (Berisi simpulan dan saran)

: (Berisi pustaka yang dirujuk dalam uraian naskah) 
5. Referensi sumber dalam teks artikel ditulis dengan menggunakan side note, contoh: (Jalalluddin, 1991:79); (Taufik, 2005;350); (Hamid dan Madjid, 2011:43). Sementara penulisan daftar pustaka disusun dengan ketentuan. Nama Pengarang. Tahun Terbit. Judul (dicetak miring). Kota Terbit: Nama Penerbit. Contoh: Koentjaraningrat. 2010. Manusia dan Kebudayaan Di Indonesia. Jakarta: Djambatan.

Daftar pustaka hanya memuat pustaka/sumber yang dirujuk dalam uraian dan disusun menurut abjad, tanpa nomor urut.

6. Naskah yang dimuat akan disunting kembali oleh redaksi tanpa mengubah isinya.

7. Naskah yang ditolak (tidak bisa dimuat) akan dikirim kembali ke penulis dengan pemberitahuan tertulis dari redaksi atau alamat email.

8. Penulis yang naskahnya dimuat akan mendapatkan 1 (satu) majalah nomor yang bersangkutan.

9. Contact Person: Treny (085357344704) dan Mainur (081373165553). 